\title{
SASTRA SUFISTIK PERSIA; CITRA KEHIDUPAN \\ DALAM MASNAWI MAKNAWI \\ KARYA JALALUDDIN RUMI
}

\author{
Bastian Zulyeno \\ Prodi Arab \\ Fakultas Ilmu Pengetahuan Budaya \\ Universitas Indonesia \\ baszeno@gmail.com
}

\begin{abstract}
Persian literature has been developing since hundreds of years $B C$, this can be seen from the Zoroastrian or "Avesta" holy books. This book contains mostly about the praise and greatness of the Lord "Ahuramazda" written in the form of poetry. The name Avesta itself comes from the name of the writing and the language used in this book, therefore the researchers named this holy book with the name Avesta. Avesta is the root of ancient Persian before Parthi, Soghdi and Pahlavi. One of the scientific traditions inherited by the Persians is the science of Tasawwuf and Sufistic literature is the biological child born of him. Persian land has long been fertile with Sufism thought with its typical eastern imagination. One of the Persian maestros whose thinking was global was Jalaluddin Muhammad ibn Sultan al Ulama Bahauddin Muhammad ibn Huasain ibn khatibi Bakri Balkhi who was better known as Rumi and all the works he left behind used Persian. Sufistic or mystical literature is a work produced by Sufi poets or a wise person whose poetry is based on his Sufistic experience. This paper discusses the main theme based on several verses of poetry contained in the Masnawi Maknawi of the great works of the great Persian Sufi of the 13th century.
\end{abstract}

Keywords: Rumi, Life, Masnawi, Persia, Sufistic

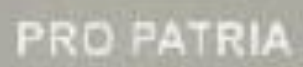

\section{A. Pendahuluan}

Pembicaraanku tidak lebih dari tiga hal

Aku dulu mentah, sekarang masak dan menjadi hangus" (Rumi)

Jalaluddin Rumi yang lahir di Balkh, pada tanggal 30 September 1207 dan wafat pada tanggal 17 December 1273 di Konya. Sampai usianya 35 tahun, tidak tampak tanda bahwa Rumi berhasrat menjadi seorang sufi apalagi penyair. Dia memang telah mempelajari tasawwuf pada Syeikh Al Tarmizi, seorang sufi terkemuka dari Khorasan yang datang ke Konya pada tahun 1232. Bahkan ketika Rumi belajar di Madrasah Tinggi Halawiyah, Aleppo, Syiria. Dia sempat memperdalam studinya dalam ilmu tasawwuf, sastra dan tafsir Al Quran metode sufistik.
Kehidupannnya setelah itu hanyalah mengajarkan ilmu-ilmu formal keagamaan. Tetapi pada usia 37 tahun setelah pertemuanya dengan Syamsuddin Tabrizi seorang darwish pengembara sufi dari Tabriz, Iran, yang hadir di Konya, pada tahun 1244 , terjadilah revolusi ruhani dalam kehidupan dan keperibadian Rumi.

Di dalam sastra sufistik ada dua hal pokok yang selalu dibicarakan pertama adalah nasehat dan kedua adalah cinta. Nasehat dalam menjalani hidup dan tahapan dalam menggapai cinta sejati, cinta sejati adalah cinta makhluk kepada khaliq. Manusia tercipta karena cinta tuhan kepadanya yang ingin selalu disembah, inilah hakikat penciptaan yang berarti cinta dan wujud ini pula yang ada di setiap yang bernyawa dan memiliki naluri kasih sayang. Cinta adalah keadaan bukan bualan. Cinta yang 
sebenarnya adalah ketika sang pecinta tidak menunggu sang kekasih justru dalam diri kekasih si pecinta menjadi fana. Pecinta akan menyampaikan kehendak kekasih melalui dirinya sampai dirinya sendiri tidak memiliki kehendak. Hal ini dikuatkan dengan defenisi mahabbah yang dikemukakn oleh Qusyairi" hakikat mahabbah adalah menyerahkan seluruh wujud diri kepada kekasih hingga tidak sedikitpun tersisa untuk dirinya sendiri". Dalam hal ini ada kesulitan besar dalam menafsirkan puisi Persia ke pembaca Barat khususnya. Untuk pemahaman umum biasanya semua terjemahan puisi ada komentar/penjelasan tambahan, dalam kasus puisi Persia, kesulitan khusus adalah ketika seseorang mencoba menrjemahkan puisi mistik, selain harus mebaca literatur tasawuf, referensi sastra dan Quran juga perlu diperhatikan bentuk monorhyme yang sangat efektif dan umum dalam bahasa Persia, tetapi belum tentu cocok untuk kebanyakan bahasa lain. Sir E. Denison Ross mengatakan, karya terjemah dalam bahasa dan musik memberi efek pada pembaca untuk terpaksa mengorbankan esensi dari masalah ini. Singkatnya hasil penerjemahan jika menurut pembaca bagus berarti puisi yang terdapat dalam bahasa sumbernya lebih indah lagi.

Har cheh gooyam eshq ra sharh o bayan / Choon be eshq ayam khijl gardam azan

Gar cheh tafsir zaban roshangar ast / Liik eshq bi zaban rooshantar ast//

(Matsnawi:III)

Setiap saat aku menjelaskan makna cinta / ketika masuk di dalamnya aku malu

Walau dengan tafsir lisan menjadi terang / tetap makna cinta tanpa lisan akan lebih terang//

\section{B. PEMBAHASAN}

Allah swt berfirman: Allah mencintai mereka dan mereka mencintai allah (al- Maidah 54). Sang kekasih adalah Dia Yang Tunggal, Ahmad Ghazali seorang sufi besar Persia yang juga adik kandung Imam Ghazali menguraikan makna cinta dengan sangat indah dalam bukunya Savane e Eshgh, "Ruh datang dari ketiadaan menuju perbatasan wujud saat itu ruh sedang menunggu tunggangan cinta. Pada permulaan wujud aku tak tahu apa dicampur apa, jika zat adalah ruh maka sifat zat adalah cinta dan ruh melihat rumah kosong lalu menempatinya"

Dalam penuturannya tentang cinta mistik, Rumi melantunkan kerinduan, kesedihan, serta kegembiraannya dalam rangkaian simbol-simbol yang tak berujung -tanpa permulaan- (karena sang kekasih tiada bermula), tanpa akhir, serta tanpa terma-terma yang memadai. la kadang menggunakan beberapa konsep yang sama, tetapi dengan makna yang sungguh berbeda. Pada saat yang lain Rumi juga mengembangkan makna bathin (inner meaning) dari sebuah kata yang tunggal dengan cara yang luar biasa indah dan puitis. Semua itu dilakukannya untuk membawa para pembaca kepada kedalaman pengalaman spritualnya.

Jika berusaha menemukan beberapa pola utama dalam simbolisme dari puisi-puisi Rumi tanpa memaksakannya untuk menjadi sebuah sistem pemikiran teologis, maka kita akan langsung melihat bahwa ia menggunakan banyak gambaran tentang gejala-gejala alam. Memang inilah salah satu karakteristik puisinya yang dalam istilah penulis sendiri sebagai "refleksi langit di bumi". Artinya Rumi mengajak kita tidak memandang alam dan fenomenanya dengan sederhana. Terlalu dangkal logika ini jika hanya melihat keindahan pohon dan berhenti pada kalimat impressif, tapi pohon adalah mediasi kita untuk melihat langit (Yang Maha Tinggi) atau manuver tuhan bagi manusia untuk merenungi gejala alam.

Menurut Rumi apa yang dilihat di alam ini berasal dari alam lain di sana dan alam di sini adalah contoh dari alam di sana. Semua anggota badan kita berasal dan duplikat dari sana yang kita akan kembali juga ke sana. Akan tetapi semua perbendaharaan yang tersimpan ini tidak akan tampak jelas tanpa memilki hati yang suci, karena kau tidak akan melihat angin di musim semi, indahnya musim semi tampak pada pepohonan dan rerumputan yang terhembus angin, jadi 
melalui anginlah keindahan musim semi terkuak. Begtu juga manusia sifat lembut yang dimilki akan terus tersembunyi dan tak tampak nyata kecuali ada dari sisi dalam dan luar yang mengabarkannya. Ahli neraka merasa lebih senang tinggal di neraka daripada di dunia karena di neraka mereka sadar akan kebenaran tetapi saat mendiami dunia mereka lalai adanya haq.

Menurut Karim Zamani seorang mufassir Masnawi, ada tiga pandangan berbeda mengenai kehidupan yang biasa termaktub dalam teks-teks sastra sufistik. Pandangan pertama adalah memandang kehidupan dengan mata negatif mutlak, pandangan kedua melihat dengan datar dan hanya zhahiiriyah dan pandangan ketiga melihat kehidupan dengan sebenarnya sebagai realitas. Pandangan pertama objek pandangannya adalah dunia yang penuh fitnah dan semua yang ada di langit dan bumi berputar dan mengeluarkan fitnah. Orang-orang yang masuk dalam kelompok ini menganalogikan dunia seperti dapur panas yang di dalamnya api dari kompor-kompor menyala dan setiap orang masuk ke sana dengan tujuan mencari makanan yang mana antara satu materi dan materi yang lain saling berdekatan, mata menjadi merah dan berair dari panasnya api, dada menjadi sesak dan batuk hingga harus meninggalkan dunia dapur. Koloni manusia baru terlahir kisah ini pun akan terus terulang. Inilah kelompok orang yang melihat kehidupan sebagai objek negatif mutlak. Pandangan ke dua adalah pandangan dangkal dan datar terhadap dunia yang melihat dunia hanya tempat hidup, makan, minum dan istirahat. Orang yang menganut pandangan ke dua ini hanya ingin hidup yang terbatas pada kebahagiaan dan kenikmatan saja. Dan pandangan yang ke tiga adalah pandangan yang sebenarnya terhadap kehidupan. Menurut Rumi kehidupan bukanlah seperti pendapat pertama yang melihat kehidupan dunia dengan negatif mutlak bukan juga seperti pendapat ke dua yang hanya mencari kesenangan dan kenikmatan semata, akan tetapi Rumi lebih cenderung pada pandangan ke tiga yang melihat dunia lebih kepada hakikat tidak kepada realitas semu. Rumi dari satu sisi menganggap kematian dan kesedihan adalah kreasi kehidupan dan dari sisi lain melihat pada kebahagian hidup, tetapi ke dua sisi ini dan seluruh isi alam adalah hakikat hidup yang wajib diperhatikan melalui media cinta. Rumi selalu menggunakan metafor burung bulbul sebagai pecinta dan bunga di taman adalah kekasihnya. Pecinta sejati untuk sampai kepada kekasihnya akan melewati banyak rintangan, dia akan selalu mengucapkan selamat datang bagi setiap bala, musibah dan kesusahan di jalan cinta. Kesedihan dan atributya adalah milik semua manusia dan yang penting tidak boleh menyerah menghadapi kesedihan. Masih menurut Karim Zamani, hakikat kehidupan bagi Rumi adalah sebuah perjalalanan menuju dunia baru atau kehidupan sempurna. Seorang salik harus bisa melangkah ke depan dari alam semu menuju alam hakikat. Dunia dan kehidupan adalah rangkaian perjalanan menuju kesempurnaan dimana manusia merubah semua kelemahannya menjadi kesempurnaan yang cemerlang demi sampai kepada tujuan hidup yang sebenarnya. Di bagian lain Rumi juga mendefenisikan kehidupan hakiki dengan terlahir ke dua kali. Dalam perjalanan ini tidak perlu terburu-buru untuk sampai kepada kesempurnaan akan tetapi harus pelan-pelan. Karena dunia ini diciptakan dari atas turun ke bawah dan akan kembali ke atas perlahan satu tangga demi satu tangga menuju kediaman asli manusia.

Rumi dalam karya Masnawi jilid empat menafisrkan tentang Tuhan yang menciptakan manusia dalam tiga macam kelompok. Kelompok pertama kelompok malaikat yang hanya dianugerahi akal dan ketaatan kelompok ini tidak mengenal khianat, syahwat dan maksiat. Kelompok ke dua adalah binatang yang hanya tahu makan dan bahan makanan. Kelompok ke tiga adalah manusia kelompok yang sangat spesial dan unik yang bathinnya memiliki dua sisi, setengah hewan dan setengah lagi malaikat yang dipundaknya juga memikul amanah, karena keunikan ini akhirnya beban amanah itu 
dipikulkan kepada pundak manusia. Dalam bathin kelompok malaikat dan hewan ini tidak pernah ada peperangan, tetapi dalm bathin wujud manusia selalu terjadi konflik antara baik dan yang menolak kebaikan. Rumi juga membedakan antara wujud manusia dan jin. Manusia adalah makhluk yang sangat komplek dan rumit begitu juga jin wujud yang tersembunyi dan penuh rahasia, akan tetapi manusia lebih kuat daripada jin karena manusia dapat menyembunyikan keadaan bathinnya dari orang-orang sekelilingnya. Bisa menyembunyikan perasaan bahkan dapat menunjukkan sikap dan kondisi yang berlawanan dari bathinnya. Manusia memilki sensitifitas yang juga mampu disembunyikan dari dirinya sendiri. Hubungan antara zhahir dan bathin manusia seperti pulau di tengah lautan luas. Daratan pulau tampak jelas di tengah-tengah laut tapi ada bagian yang lebih besar dan dalam yang tidak tampak. Daratan yang tampak jelas itu bukan asli kepribadian kita, asli kita tersembunyi dengan berbagi macam jenis yang kadang kita sendiri tak menyadarinya.

Rumi menempatkan ma'rifattunnafsi sebagai ilmu yang paling tinggi hingga manusia mampu membuka tabir hikmah untuk apa dia tercipta dan untuk apa dia hidup dan ilmu itu hanya bisa diobservasi melalui diri sendiri pada akhirnya makrifat inilah yang sewaktu-waktu bisa menyelamatkan manusia dari kealpaan tujuan hidup.

Dalam studi keindahan menurut pandangan para Arif keindahan dan kajian keindahan sangatlah penting bagi semua manusia karena manusia jika tidak mempelajari studi keindahan bagaimana bisa dia menganalisis sebuah keindahan. Menurut Rumi keindahan bersumber dari satu mata air dari alam keindahan yang absulut yang dipancarkan dari alam lahut ke alam nasut. Bagi Rumi semua keindahan yang dia lihat merupakan pancaran sinar dari bulan hakikat. Dan sinar bulan itu berasal dari matahari yang lebih tinggi dan sinar cahaya mataharipun bersumber dari tempat yang lebih tinggi lagi dan begitu seterusnya. Jadi siapapun yang melihat keindahan di dunia ini dan memujinya sesungguhnya dia juga memuji sumber keindahan tersebut, pujian ini secara tidak langsung berkaitan dengan sumber asli keindahan.

Dalam bab keindahan dalam beberapa bait Rumi mengatakan apabila cinta berkaitan dengan jasad manusia jangan terlalu jauh terlena dengan keindahan tersebut. Cinta jenis ini dalam istilah Rumi adalah cinta berwarna, cinta berwarna selalu berbeda dengan cinta hakiki. Dalam cinta berwarna "bertemu kekasih" berarti terkubur dalam sebuah pusara cinta, artinya ketika sang pecinta sudah bertemu dan menyatu bersama kekasih tidak ada lagi hal yang menarik karena usaha keras dan berliku hanya pada proses dan selesai di titik "pertemuan" akan tetapi "betemu kekasih" dalam cinta hakiki akan membuat api cinta semakin berkobar dan melahap hingga antara pecinta dan kekasih menjadi satu kesatuan. Pecinta adalah identitas yang tidak bisa bebas dan merdeka dari dirinya, adalah kekasih objek semata yang dilihat dan semua yang terlihat adalah cermin juga dari bayangan indahnya sang kekasih.

Haft shahre eshq ra atthar gasht

Ma hanuuz andar ham ye kuche iem (Masnavi) Atthar telah melewati tujuh negeri cinta Dan kita masih terbungkuk diam di tengah gang sempit

Rumi dalam salah satu ceramahnya pernah berkata pecinta hakiki adalah orang yang mencintai sesuatu yang dia belum pernah melihatnya dan mendengar. "aku adalah hamba dari yang belum pernah aku lihat". Dunia ini adalah dunia penuh wajah, bukan saja dunia materi tetapi juga dunia immateri. Tuhan wajah tanpa wajah dan dunia ini adalah wajah-wajah yang bersumber dari mata air dunia sana yang tak berwajah. Hubungan alam ini dan tuhan adalah hubungan antara wajah dan tanpa wajah.

Soorat az bi soorat amad beruun

Baz shood kainna ilaihi rajiun (Masnawi)

Wajah tanpa wajah tampak keluar 
Kembali sudah seperti Inna ilaihi raji'un

Lantas bagaimana wajah tanpa wajah bisa tampak, ini salah satu dari rahasia alam dan salah satu dari rahasia itupun bisa kita ketahui sedikit saja atau tidak mungkin membuka seluruh tabir. Karena kita adalah wujud yang berasal dari eksistensi yang tak bertepi, disinilah batas wilayah fisik dan metafisika yang merupakan area rahasia yang menghubungkan antara ruh dan jasad atau hubungan antara makrokosmos dan mikrokosmos atau yang lebih spesifik lagi adalah hubungan antara wajah dan tak berwajah. Dan yang dimaksud dengan tak berwajah adalah yang tidak bisa di katagorikan dalam wujud apapun karena sebenarnya tuhan adalah lebih dari semua wujud dan semua wujud ada di tengah-tengah wujudnya. Kalau kita menggambarkan tuhan lebih dari ini berarti kita telah membatasi wujud tuhan.

Har chie andishei paziraii fanast

Anke dar andishe nayad an khudast (Masnavi Jilid II, 3112)

Semua yang terpikir olehmu akan fana

Dan semua yang ada dalam pikiran tak tersisa selain tuhan

Satu bait puisi di atas terinspirasi dari ayat quran surat Arrahman ayat 26-27 "kullu man a'laiha fani wa yabqa wajhi rabbika dzul jalali wal ikram". Semua sifat dapat ditemukan di seluruh alam. Tetapi di alam lahut kita tidak termasuk dari siifat-sifat ini, bahkan sifat cinta itu sendiri yang tampak universal. Ketika kita berbicara tentang cinta ilahi, bukanlah cinta yang tadinya benci kemudian menjadi suka atau cinta yang memilki lawan kata yaitu benci, tetapi sifat yang berbeda yang tidak memiliki paradoks dan konflik keragaman kata dan bilangan. Jika ketika kita berbicara tentang keesaan bukanlah keesaan yang berasal dari banyak kesatuan atau integritas kesatuan karena jika berasal dari banyak bilangan berarti tuhan adalah esa dari tunggal yang berbilang dan tuhan bukan kesatuan yang berbilang non numerical unity.
Ma ze daryaim o darya miravim / ma ze balaim o bala miravim

Ma ze inja o ze anja nistim / Ma zebi jaim o be ja miravim

Keshti nuhim dar daryae ruuh/ la jarm bi dast o bi pa miravim// (Masnawi:II)

Kami datang dari laut dan kembali ke laut / kami datang dari atas dan kembali ke atas.

Kami dari sini dan bukan dari sana/ kami datang dari tiada ruang dan kembali ke tak be -ruang Kami adalah bahtera nabi nuh di lautan ruh/ tak maaslah kalau kami pergi ke sana tanpa tangan dan kaki//

Fana adalah menyatunya setetes air dengan laut, bukan berarti setetes tadi akan sirna ditelan laut akan tetapi tenggelam dan menyatu dalam lautan luas. Kefanaan bukan berarti kehancuran tapi ini adalah imajinasi yang harus dimilki setiap manusia. Hancur berarti seluruh kesempurnaan yang dimilki akan sirna. Sempurna adalah kesempurnaan wujud manusia dijaga di saat bersamaan menyatu dengan kesempurnaan yang tak terbilang dan tak terbatas. Berangkat dan sampai bukan mendapatkan hasil "nol".

Sifat terpenting dari sebuah karya sastera yang diciptakan "secara benar" ialah kemampuan penulis merombak kesadaran dan psikologi pembacanya. Sesuai dengan taraf yang dicapai oleh penyair dalam usahanya untuk meninggi ke dunia rohaniyah, atau juga berarti merasuk ke dalam diri sendiri, maka karya itu bisa memainkan peran yang berlainan. Sesuatu karya bisa memberi harmoni ke dalam jiwa manusia yang resah, atau memperkuat kebijksanaannya, atau pada tarafnya yang tertinggi menyempurnakan pengenalan dan mempersiapkan diri untuk penghayatan ilham. (Braginsky, V.I., 1983: 204210)

\section{KESIMPULAN}

Pengalaman religius yang paling dalam adalah sebuah mysterium ineffabile, sebuah pengalaman yang tidak terlukiskan. Pengalaman itu mengatasi ruang dan waktu sehingga karenanya, ia pun tidak 
dapat diekspresikan secara memadai oleh kata-kata yang terikat oleh ruang dan waktu (Annemarie Schimmel)

Perpaduan nilai estetika dan spiritual menghasilkan karya seni yang tak luntur dan terus abadi sepanjang peradaban manusia. Hampir semua karya dalam bidang tasawuf sampai ke tangan kita, produk ratusan tahun silam masih relevan untuk dikaji sampai saat ini, dengan metafora yang berlaku sepanjang zaman hal ini disebabkan karena pendahulu dari kalangan sufi yang selalu mengkaji di depan murid-muridnya sehingga selalu dicatat dan dibahas. Sastra sufistik mengungkapkan objek metafisika dengan bahasa yang tidak biasa, hal ini juga yang membuat pendengar dan pembaca selalu berkesan.

Jalaluddin Rumi menyuguhkan semua karyanya berdasarkan pengalaman spiritual yang dialaminya dalam kehidupan zhahir dengan mengaitkannya dengan alam metafisika, mungkin tidak cukup mudah bagi kita untuk memahami pengalaman spiritual seseorang yang kita sendiri tidak atau belum merasakannya, karena tiap-tiap kita juga memilki pengalaman spiritual masing-masing, tapi itulah karya sastra khususnya puisi menjadi indah dan berkesan karena lahir dari sebuah rasa bathin manusia yang terdalam dan tidak mungkin terukur (bz)

\section{DAFTAR PUSTAKA}

1. Abdul Hadi. WM, (1999) Kembali ke Akar kembali ke Sumber: Esai-esai Sastra Profetik dan Sufistik, Jakarta: Pustaka Firdaus.

2. , (2010) Jejak Persia dalam

Sejarah, Kebudayaan dan Sastra Melayu. Makalah dalam "Dialog Budaya” di KBRI Tehran, Iran.

3. , (2008) Sastra Persia Dalam

Lintasan Sejarah

4. Al Hujwairi, Kasyful Mahjub, Tahuuri Publisher, Tehran:2011.

5. Assagaf, Muhammad Hasyim, (2009) Lintasan Sejarah Iran dari Dinasti Achaemenia-
Revolusi Islam, Jakarta: Kedutaan Besar Republik Islam Iran

6. Axworthy, Michael, (2008) Iran Empire of the Mind A history from Zoroaster to The Present Day, London: Penguin Books.

7. Braginsky, V.I. (1998) Yang Indah, Yang Berfaedah Dan Kamal: Sejarah Sastra Melayu Dalam Abad 17-19. Jakarta: INIS.

8. (1993) Tasawuf Dan

Sastra Melayu, Kajian dan Teks-Teks, Jakarta: RUL.

9. Bukhari Lubis, Muhammad, (1990) Bunga Rampai Sastra Parsi, Kuala Lumpur: Dewan Bahasa dan Pustaka

10. Dekhodā, Aliakbar, (1998) Loghatnāme Dekhodā, Tehran: Tehran University Publication.

11. Sadeqi, Ja'far Modarres, Maqalat Maulana, (FIHI MA FIHI), Markaz Publisher, Tehran:2008.

12. Shamisa, Siruus, guzideh gazaliyyat e Movlavi, Qetreh Publisher, Tehran:2007

13. Zamani, Karim, Sharhe Jame Masnavi Maknavi, Ettelaat Publisher, Tehran:2010. 